\title{
PEMBELAJARAN BERBASIS GOOGLE CLASSROOM, GEOOGLE MEET DAN ZOOM GURU SMP NEGERI 2 BATUBARA
}

\author{
Rakhmawati Purba, Aisyah Siregar, Rumiris Siahaan, Suci Etri Jayanti S., \\ Rusmewahni \\ STIE Bina Karya Tebing Tinggi \\ Email : rakhma.purba@gmail.com
}

\begin{abstract}
The Covid 19 pandemic has changed the entire order of life, especially the world of education. Through Government Policy, the face-to-face teaching system in the teaching and learning process is transferred to the online system or known as the online system. The problems that arise in choosing the right method to use in the teaching and learning process in the midst of this pandemic are a dilemma for teachers. Some of the alternative applications offered must be adapted to the conditions of the school, teachers and students. The application used must be able to be accessed and understood by every teacher and student so that learning objectives can be achieved. The purpose of carrying out this community service activity is to implement the Tri Dharma of Higher Education, especially Community Service, to equip teachers to have an understanding and knowledge of online learning applications and be able to use them in the online teaching and learning process. The method used in this service activity is to use a lecture system, presenting materials related to online teaching applications based on Google Classroom, Google Meet and Zoom and direct practice using these applications with the help of a practical companion team to 20 UPTD teachers of SMP Negeri 2 Air White. The results obtained by the teachers can understand and understand using online teaching methods so that the learning process can run effectively in accordance with the objectives of the National Curriculum in the midst of the Covid 19 Pandemic.
\end{abstract}

Keywords: Learning, Google Classroom, Google Meet, Zoom.

\begin{abstract}
Abstrak
Pandemi Covid 19 telah mengubah seluruh tatanan kehidupan, terutama dunia pendididkan. Melalui Kebijakan Pemerintah, sistem pengajaran tatap muka dalam proses belajar mengajar dialihkan kesistem on line atau dikenal dengan sistem daring. Permasalahan yang timbul dalam memilih metode yang tepat dipakai dalam proses belajar mengajar ditengah pandemi ini menjadi dilema bagi para guru. Beberapa alternatif aplikasi yang ditawarkan harus disesuaikan dengan kondisi sekolah, guru dan peserta didik. Aplikasi yang digunakan harus mampu diakses,dan pahami oleh setiap guru dan peserta didik agar tujuan dalam pembelajaran tetap tercapai. Tujuan dilaksanakan kegiatan pengabdian kepada masyarakat ini adalah untuk Mengimplementasikan Tri Dharma Perguruan Tinggi, khususnya Pengabdian Kepada Masyarakat, membekali Guru-Guru agar memiliki pemahaman dan pengetahuan tentang aplikasi pembelajaran daring serta dapat mempergunakannya dalam proses belajar mengajar secara on line. Metode yang dipakai pada kegiatan pengabdian ini adalah menggunakan sistem ceramah, memaparkan materi-materi yang berhubungan dengan aplikasi pengajaran daring berbasis Google Classroom, Google Meet dan Zoom serta praktek langsung pemakaian aplikasi tersebut dengan bantuan team pendamping praktek terhadap 20 orang guru UPTD SMP Negeri 2 Air Putih. Hasil yang diperoleh para guru dapat memahami dan mengerti menggunakan metode pengajaran daring sehingga proses pembelajaran dapat berjalan efektif sesuai dengan tujuan Kurikulum Nasional di tengah Pandemi Covid 19.
\end{abstract}

Kata Kunci : pembelajaran, google classroom, google meet, zoom. 


\section{Pendahuluan}

Infeksi COVID-19 yang disebabkan virus corona merupakan suatu pandemik baru dengan penyebaran antar manusia yang sangat cepat. Derajat penyakit dapat bervariasi dari infeksi saluran napas atas hingga ARDS. Diagnosis ditegakkan dengan RT-PCR, hingga saat ini belum ada terapi antivirus khusus dan belum ditemukan vaksin untuk COVID-19. Diperlukan pengembangan mengenai berbagai hal termasuk pencegahan di seluruh dunia (Handayani 2019)

Dimasa Pandemic Covid 19 yang mewabah hampir seluruh dunia, terutama negara kita, Indonesia mengakibatkan Pemerintah melalui Menteri Pendidikan mewajibkan sekolah-sekolah dan dunia pendidikan melakukan kegiatan belajar mengajar melalui sistem on line atau yang lebih familiar dengan kata daring. Adapun tujuan kebijakan pemerintah tersebut dimasa Pandemi Covid 19 ini agar memutus rantai penularan virus yang membahayakan tersebut di tengah masyarakat Indonesia terutama para siswa dan para pendidik. Sementara kegiatan pembelajaran harus terus dijalankan sesuai tuntutan Kurikulum Nasional agar terlaksana pencerdasan kehidupan anak bangsa. Untuk itu para pamong pendidikan dituntut harus mampu mengubah pola ajar dari konvensional (tatap muka) dengan pembelajaran sistem daring dari rumah masing-masing siswa dan guru.

Bagaimana memilih metode yang tepat dan manajemen waktu ditengah pandemi menjadi dilema untuk guru. Beberapa alternatif aplikasi yang ditawarkan harus di sesuikan dengan kondisi sekolah dan peserta didik. Aplikasi yang digunakan harus mampu diakses,dan pahami oleh setiap guru dan peserta didik agar tujuan dalam pembelajaran tetap tercapai.

Pembelajaran tidak sekedar membagikan materi pembelajaran dalam jaringan internet juga ada proses kegiatan belajar mengajar secara online. Jadi, perbedaan pokok antara pembelajaran online dengan sekedar mambagi materi pembelajaran online adalah adanya interaksi yang terjadi selama proses pembelajaran. Interaksi dalam pembelajaran terdiri dari interaksi antara pembelajar (siswa) dengan pengajar dan atau fasilitator (pengajar), dengan sesama pembelajar (siswa) lainnya, dan dengan materi pembelajarannya itu sendiri (Belawati, 2019)

Teknologi Informasi dan Komunikasi atau ICT (Information and Communication Technology) yang berkembang sangat pesat pada dasa warsa terakhir ini membawa dampak yang luar biasa pada berbagai sektor kehidupan kita seperti bisnis, hiburan dan pendidikan. Pengaruh pada bidang pendidikan sangat jelas kita rasakan. Kita bisa melihat bagaimana ICT mempengaruhi para siswa belajar dengan sumber informasi yang begitu melimpah serta para guru mengubah cara mengajar untuk mengantisipasinya. Tantangan yang dihadapi para guru tentulah tidak semakin ringan, karena siswa diharapkan bisa bersaing secara global yang bercirikan ICT. Guru saat ini tidak lagi sebagai pusat sumber belajar dan penyampai informasi utama, tetapi lebih dari itu yakni mampu berperan sebagai fasilitator, pendamping, pembimbing, dan sekaligus sebagai patner dalam mengembangkan skill dan pengetahuan.(Suartama,2014)

SMP Negeri 2 Air Putih yang terletak di Desa Pematang Panjang Kabupaten Batubara adalah sebuah sekolah menengah pertama yang mempunyai 20 (dua puluh) orang tenaga pendidik berpendidikan Sarjana. Dari ke 20 orang tenaga pendidik tersebut 4 (empat) orang guru yang mempunyai jabatan fungsional yaitu kepala sekolah, wakil kepala 
sekolah (wakasek), wakil kepala sekolah bagian kurikulum, wakasek bagian kesiswaan, wakasek sarana dan prasarana dan wakasek bagian humas. Sekolah tersebut memiliki siswa kelas VII sebanyak 3 kelas, kelas VIII sebayak 3 kelas dan kelas IX juga ada 3 kelas. Masing-masing kelas memiliki siswa berkisar $36-40$ orang.

Mata pencaharian di Desa Pematang Panjang umumnya sebagian besar adalah petani. Sehingga waktu mereka lebih banyak di ladang mengurus lahan pertanian. Para ibu sebagai ibu rumah tangga turut membantu kaum suami dalam mengolah ladang dan juga mengerjakan pekerjaan rumah. Pada masa Pandemi Covid ini, anak sekolah diharuskan menjalani masa isolasi dan proses belajar mengajar dilakukan dari rumah masing-masing siswa, sehingga memberatkan kaum ibu dalam membimbing anak-anaknya sebagai pengganti guru di rumah. Peran orangtua makin bertambah selama masa Pandemi ini.

Penggunaan aplikasi Zoom Meeting, Google Meet dan Google Classroom terhadap tenaga pendidik UPTD SMP Negeri 2 Air Putih desa Pematang Panjang sebagai Aplikasi yang akan dipakai para guru dalam melaksanakan kegiatan belajar mengajar, dimana pemakaian aplikasi tersebut belum begitu familiar di kalangan para guru. Dalam mengatasi permasalahan yang dihadapi oleh guru-guru, melalui Program Pengabdian Kepada Masyarakat, Dosen STIE Bina Karya berkolaborasi dengan Kelompok Kerja Kepala Sekolah UPTD SMP Negeri 2 Air Putih mengadakan kegiatan Tridharma Perguruan Tinggi, yaitu PKM dalam hal ini para guru pamong diUPTD SMP Negeri 2 Air Putih tersebut.

Tujuan Kegiatan PKM dengan Judul " Pembelajaran Berbasis Google Classroom Di Masa Pandemi Covid 19 Sebagai Media Belajar Mengajar Guru UPTD SMP Negeri 2 Air Putih, Desa Pematang Panjang, Kabupaten Batu Bara, bertujuan untuk:

1. Mengimplementasikan Tri Dharma Perguruan Tinggi, Khususnya Pengabdain Kepada Masyarakat.

2. Membekali Guru-Guru UPTD SMP Negeri 2 Air Putih desa Pematang Panjang agar memiliki pemahaman dan pengetahuan tentang Zoom Meeting, Google Meet, dan Google Classroom.

3. Membantu memberikan pengetahuan dan pemahaman tentang pemakaian Zoom Meeting, Google Meet dan Google Classroom.

4. Memberikan contoh cara pemakaian Zoom Meeting, Google Meet dan Google Classroom

Sesuai dengan penelitian Mustakim, efektivitas pembelajaran daring menggunakan media online selama pandemi covid-19 pada mata pelajaran matematika bahwa inovasi pembelajaran dengan menggunakan media online sangat efektif $(23,3 \%)$, efektif $(46,7 \%)$, dan menilai biasa saja (20\%), tidak efektif (10\%). Untuk membuat pembelajaran matematika lebih efektif lagi, kedepannya guru atau pendidik diharapkan menerapkan sepuluh saran yang diberikan peserta didik, yakni

a) pembelajaran dilakukan melalui video call;

b) pemberian materi pembelajaran yang ringkas;

c) meminimalisir mengirim materi dalam bentuk video berat untuk menghemat kuota;

d) pemilihan materi dalam video harus berdasarkan kriteria bahasa yang mudah dipahami;

e) tetap memberikan materi sebelum penugasan;

f) pemberian soal yang bervariatif dan berbeda tiap peserta didik;

g) pemberian tugas harus disertakan cara kerjanya; 
h) memberikan tugas sesuai dengan jadwal pelajaran;

i) mengingatkan peserta didik jika ada tugas yang diberikan; dan

j) mengurangi tugas.

Hasil dari penelitian Sobron dan kawan-kawan, dampak positif yang didapat dari proses pembelajran Daring Learning yaitu dapat menciptakan komunitas pembelajaran. Proses pembelajaran IPA dapat berlangsung bersama dengan teman-teman pada komunitas, efisiensi waktu dan biaya dalam pembelajaran yang dapat dilakukan dimana saja dan kapan saja. Siswa tidak perlu menghabiskan waktu berjam-jam untuk belajar di kelas dan bahan belajar di akses dengan kecanggihan teknologi, materi-materi pembelajaran dapat diunduh dan dapat dipelajari kapan saja tanpa dibatasi waktu

\section{Metode}

Kegiatan Pengabdian Kepada Masyarakat merupakan bagian dari Tridharma Perguruan Tinggi selain melaksanakan Pengajaran dan Penelitian. Setiap Dosen dituntut untuk melakukan pengabdian minimal 1 (satu) x dalam 1 semester. Jadi dalam 1 tahun ajaran wajib melaksanakan 2 (dua) $x$ pengabdian kepada masyarakat sesuai dengan bidang ilmu yang diemban. (Buku Pedoman LPPM STIE Bina Karya, 2018)

Adapun Bentuk Kegiatan bidang pengabdian kepada masyarakat meliputi: Pendidikan kepada Masyarakat, Pelayanan kepada masyarakat, Penerapan Hasil Penelitian dan Kaji Tindak.

1. Pendidikan Kepada Masyarakat.

Kegiatan pendidikan kepada masyarakat ditujukan untuk mengembangkan kemampuan sumberdaya manusia melalui pendidikan non formal. Bentuk-bentuk kegiatannya dapat berupa: pendidikan keluarga, panataran, kursus-kursus, lokakarya, penyuluhan, latihan, bimbingan kerja/teknis, proyek percontohan, dan kelompok belajar.

2. Pelayanan Kepada Masyarakat.

Pelayanan yang dimaksud adalah pemberian layanan oleh Sivitas Akademika secara profesional kepada masyarakat yang memerlukan. Pelayanan yang diberikan berbentuk : perencanaan kota, studi kelayakan, bimbingan dan penyuluhan dalam arti luas, pelayanan manajemen, bantuan dan konsultasi bidang ekamoni, UMKM.

3. Penerapan Hasil Penelitian.

Dapat berupa : penerapan teknologi tepat guna, penerapan hasil-hasil penelitian, penerapan berbagai ilmu terapan dan sebagainya

4. Kaji Tindak

Kaji tindak adalah salah satu bentuk pengabdian kepada masyarakat dengan cara melaksanakan kegiatan (action) yang mampu memecahkan permasalahan yang dihadapi oleh masyarakat. Tujuannya untuk mengembangkan kemampuan dan pendekatan baru serta memecahkan masalah dengan penerapan langsung gagasan-gagasan terhadap masalah-masalah aktual dalam masyarakat atau di dunia usaha.

Kegiatan pengabdian kepada masyarakat ini dilakukan dengan tiga (3) sesi dan melibatkan beberapa team sehingga setiap anggota team dapat terjun langsung 
memberikan pelatihan tentang penggunaan aplikasi berbasis Google Classroom, Google Meet, dan Aplikasi Zoom Kegiatan ini sebagai kerangka pemecahan masalah bagi para guru UPTD SMP Negeri 2 Air Putih, maka dilakukan dalam bentuk pemaparan materi terlebih dahulu sebelum praktek dan latihan langsung tantang aplikasi tersebut, dengan beberapa tahapan pelaksanaan kegiatan diantaranya:

1. Persiapan

a. Melakukan kontak awal dengan pihak sekolah UPTD SMP Negeri 2 Air Putih untuk menelusuri kemungkinan pelaksanaan kegiatan pengabdian masyarakat dan prosedur yang harus dijalankan berkaitan dengan pelaksanaan kegiatan, serta menentukan pertemuan awal untuk membahas pelaksanaan kegiatan

b. Tahap obervasi berupa survei awal, melakukan pertemuan secara langsung dengan kepala sekolah dan wakil kepala sekolah. Menelusuri lebih dalam mengenai kemampuan para guru dalam memakai aplikasi berbasis internet.

c. Membahas hari dan tanggal pelaksanaan kegiatan.

d. Mempersiapkan team yang akan memaparkan materi dan team pendamping pelatihan aplikasi.

2. Pelaksanaan Pengabdian Kepada Masyarakat.

a. Pemaparan materi tentang Google Classroom oleh team 1 sebelum diadakan praktek langsung tentang pemakaian aplikasi dan tanya jawab seputar aplikasi tersebut.

b. Pemaparan materi tentang Google Meet oleh team 2 dan dilanjutkan dengan praktek pemakaian aplikasi.

c. Pemaparan materi Zoom oleh team 3 dilanjutkan dengan praktek langsung serta tanya jawab.

3. Tindak lanjut.

Setelah pemaparan materi ke 3 topik ( Google Classroom, Google Meet dan Zoom), para guru diminta melakukan praktek langsung dengan didampingi oleh team pendamping Dosen STIE Bina Karya yang sedang melakukan pengabdian kepada masyarakat. Dalam melakukan praktek tersebut para guru dapat menguasai penggunaan Aplikasi Pembelajaran, hal ini terlihat dari hasil praktek dimana setiap peserta pelatihan mampu mengoperasikan Aplikasi Google Classroom, Google Meet dan Zoom didampingi Dosen pendamping praktek.

4. Evaluasi.

Seminggu setelah dilakukan kegiatan pengabdian tersebut, maka team Dosen STIE Bina Karya melakukan evaluasi melalui Aplikasi Zoom yang melibatkan seluruh guru SMP Negeri 2 Air Putih secara Virtual dari tempat masing-masing.

\section{Hasil dan Pembahasan}

Pengabdian kepada masyarakat yang dilakukan Dosen STIE Bina Karya adalah usaha untuk membaktikan ilmu yang berupa teori dan mempraktekkannya di masyarakat, dalam hal ini guru-guru SMP Negeri 2 Air Putih. Selain membaktikan diri juga menyebarluaskan ilmu pengetahuan, teknologi, dan seni kepada masyarakat. 
Kegiatan PKM dengan tema Pembelajaran Berbasis google classroom, geoogle meet dan zoom di Masa Pandemi Covid 19 bagi guru UPTD SMP Negeri 2 Air Putih Desa Pematang Panjang Kabupeten Batu Bara dengan tahapan sebagai berikut :

Tabel 1. Kegiatan Pengabdian Kepada Masyarakat

\begin{tabular}{|c|c|c|c|}
\hline No & Tanggal & Kegiatan & Tempat \\
\hline 1. & 4 Juli 2020 & $\begin{array}{l}\text { 1. Survey / cek lokasi } \\
\text { 2. Pertemuan dengan pihak sekolah } \\
\text { 3. Permohonan izin dan diskusi soal lokasi } \\
\text { serta arahan persiapan guru }\end{array}$ & Desa Pematang Panjang \\
\hline 2. & 7 Juli 2020 & $\begin{array}{l}\text { Persiapan Pengabdian } \\
\text { 1. Brefing dan persiapan kegiatan } \\
\text { 2. Persiapan teknik Pengabdian } \\
\text { 3. Persiapan Team } 1,2 \text { dan } 3 \text { (pemateri dan } \\
\text { pendamping praktek) }\end{array}$ & $\begin{array}{l}\text { Kampus STIE Bina } \\
\text { Karya }\end{array}$ \\
\hline 3. & 8 Juli 2020 & $\begin{array}{l}\text { Pelaksanaan Pengabdian } \\
\text { 1. Pembukaan oleh kepala sekolah } \\
\text { 2. Pemaparan materi penggunaan aplikasi } \\
\text { google classroom } \\
\text { 3. Pemaparan materi penggunaan aplikasi } \\
\text { google meet } \\
\text { 4. Pemaparan materi penggunaan aplikasi } \\
\text { zoom } \\
\text { 5. Praktek Aplikasi } \\
\text { 6. Tanya Jawab } \\
\text { 7. Simulasi Penggunaan Aplikasi } \\
\text { 8. Penutupan }\end{array}$ & $\begin{array}{l}\text { Ruangan Guru UPTD } \\
\text { SMP Negeri } 2 \text { Air Putih } \\
\text { Desa Pematang Panjang }\end{array}$ \\
\hline 4. & 15 Juli 2020 & Evaluasi & $\begin{array}{l}\text { Pemakaian Aplikasi } \\
\text { Zoom secara virtual }\end{array}$ \\
\hline
\end{tabular}

Manfaat dari kegiatan pelatihan ini memberikan hasil efektif dan efisien dalam meningkatkan proses belajar mengajar. Hal ini dapat dilihat dari tingkat antusias peserta didik dalam mengikuti proses belajar mengajar secara virtual. Namun kemampuan perekonomian setiap siswa yang berbeda-beda, menjadi kendala dalam pemenuhan fasilatas penunjang kegiatan ( hp android / laptop ). Kendala lain yang ditemukan, tidak semua operator seluler memiliki jaringan yang kuat di Desa Pematang Panjang Kecamatan Air Putih tersebut.

\section{Kesimpulan}

1. Team Dosen Pengabdian Kepada Masyarakat STIE Bina Karya dapat mengaplikasikan ilmu yang dimiliki kepada masyarakat dan mampu menjalankan salah satu fungsi Tri Dharma Perguruan Tinggi di masa Pandemi Covid 19.

2. Bagi Tenaga Pengajar UPTD SMP Negri 2 Air Putih memperoleh ilmu yang bermanfaat dan dapat diterapkan pada masa Pandemik. 
3. Menghilangkan kekawatiran para orangtua siswa terhadap pembelajaran yang sempat terkendala secara tatap muka yang digantikan dengan sistem virtual.

4. Kepada seluruh siswa UPTD SMP Negeri 2 Air Putih menambah wawasan dalam kegiatan belajar mengajar berbasis teknologi.

\section{Daftar Pustaka}

Buku Panduan LPPM STIE Bina Karya tahun 2017.

Belawati, Tian. (2019). Pembelajaran Online Penerbit: Universitas Terbuka.

Bayu, Rani Rani, Meidawati S, Sobron A.N . (2019). Persepsi Siswa dalam Studi Pengaruh Daring Learning terhadap Minat Belajar IPA, SCAFFOLDING: Jurnal Pendidikan Islam dan Multikulturalisme, 1(2).

Handayani. Diah, Dwi Rendra Hadi, Fathiyah Isbaniah,Erlina Burhan,Heidy Agustin, (2020). Penyakit Virus Corona 2019. Jurnal Respir Indo, 40(2).

Kadek. I Suartama. (2014). E-Learning Konsep dan Aplikasinya, pnerbit jurusan teknologi pendidikan fakultas ilmu pendidikan Universitas pendidikan Ganesha.

Mustakim. (2020). Efektivitas pembelajaran daring menggunakan media online selama pandemi covid-19 pada mata pelajaran matematika. Journal of Islamic Education, 2(1).

Riadi, M. (2014). Pengertian , Karaktiristik dan Manfaat E-. 4-6. SATRIO, A. (2011). Kendala Dan Penerapan E-Learning. Journal Information, 10, 1-16.

Setiawan, P. (2020). Pengertian E-learning Pengertian E-learning Menurut Para Ahli Karakteristik E-learning Manfaat Elearning.

Suhery, Trimardi Jaya Putra, \& Jasmalinda. (2020). Sosialisasi Penggunaan Aplikasi Zoom Meeting Dan Google Classroom Pada Guru Di Sdn 17 Mata Air Padang Selatan. Jurnal Inovasi Penelitian, 1 (3). 